Samborska Oksana, PhD, Associate Professor of the Department of Administrative Management and Alternative Energy Sources, Vinnitsa national agrarian university, Vinnitsa, Ukraine

ORCID ID: 0000-0002-1911-9138

e-mail: super_Oksana30@ukr.net

\title{
Social and Economic Indicators of Ukraine's Development
}

\begin{abstract}
The current state of the economy with the deterioration of social results about transformational transformations due to the lack of a system for managing social dynamics in connection with the transition to innovative sources of socio-economic development, which in turn raises the issue of managing such changes. The economic development of the country concerns not only money, but also the increase of the general welfare of the population. The way to improve the better life and economic development of the country is possible taking into account the transformation processes, but achieving this involves solving a set of goals and objectives facing governments at all levels. Economic and social development of the regions of Ukraine today seeks to be better. The delimitation of regions is caused by the level of the average wage, as well as the total per capita income. The study of indicators of socio-economic development requires clear and precise actions on the part of the state and local self-government. The development of strategies for a certain period helps to improve the situation in the regions of Ukraine, but it is a temporary phenomenon that in some cases it is not a managed system. Today there is a problem of economic development, social protection of low-income groups and health care, people of retirement age and so on. All human and civil rights are equal and interrelated, and therefore they must be equally protected by the state. All human rights and civil rights must be protected by the state: man, his life and health, honor and dignity, inviolability and security - the highest social value; free development of personality is determined by the Constitution of Ukraine. The study outlines the relationship and interdependence of local budget revenues from subsidies and subventions of the state budget, economic activity of the population, as well as the unemployment rate is an important indicator of the general state of the economy.
\end{abstract}

Keywords: economics; wages; gross domestic product; budget.

\section{УДК 33.338}

Самборська О. Ю., кандидат економічних наук, доцент кафедри адміністративного менеджменту та альтернативних джерел енергії, Вінницький національний аграрний університет, Вінниця, Україна

\section{Соціально-економічні показники розвитку України}

Анотація. Теперішній стан економіки з погіршенням соціальних результатів трансформаційних перетворень характеризується відсутністю системи управління суспільною динамікою через перехід на інноваційні джерела забезпечення соціально-економічного розвитку, а це активізує питання щодо надання таким змінам керованого характеру. Економічний розвиток країни стосується не тільки грошей, але і збільшення загального добробуту населення. Шлях до поліпшення життя та економічного розвитку країни можливий з урахуванням трансформаційних процесів, але досягнення цього передбачає вирішення комплексу цілей та завдань, що стоять перед органами управління всіх рівнів. Економічний та соціальний розвиток регіонів України сьогодні має покращуватися. Розмежування областей спричинене рівнем середньої заробітної плати, а також загальним доходом на душу населення. Вивчення показників соціально-економічного розвитку вимагає чітких і точних дій з боку держави та місцевого самоврядування. Розробка стратегій розвитку на певний період сприяє покращенню ситуації в регіонах України, але є тимчасовим явищем. Сьогодні існує проблема економічного розвитку, соціального захисту малозабезпечених категорій населення та охорони здоров'я, людей пенсійного віку тощо. Усі права людини та громадянина є рівними та взаємопов'язаними, а тому вони повинні бути однаково захищені з боку держави. Всі права людини та громадянські права повинні бути захищені державою: життя та здоров'я людини, їі честь та гідність, недоторканість та безпека (ст. 3); вільний розвиток особистості (cm. 23), що визначається Конституцією України. у дослідженні окреслено взаємозв'язок та взаємозалежність доходів місцевих бюджетів від дотацій та субвенцій державного бюджету.

Ключові слова:: економіка; заробітна плата; валовий внутрішній продукт; бюджет.

Formulation of the problem. Structural modernization of the economy, improvement of business conditions, impetus for the development of domestic industry is an important basis for dynamic growth, which is planned to provide a number of systemic reforms to achieve the goal.

Analysis of recent research and publications. Strategic vectors for the education of social and economic indicators of Ukraine's development are considered by many scholars and practitioners, including O. Popovych,
N. Didenko, L. Pronko, T. Kolesnik, O. Samborska, O. M. Yatsun.

Formulation of research goals. The purpose of this article is to systematize social and economic indicators of Ukraine's development.

Outline of the main research material. The Cabinet of Ministers of Ukraine on March 29, 2020 changes to the main macroeconomic indicators of economic and social development of Ukraine for 2020 (approved by the 
Cabinet of Ministers of 15.05.2019 № 555). The reasons for such changes were the deviation of the actual level of economic and social development of Ukraine from the forecast parameters, as well as the application of restrictive anti-epidemic measures. Among the key changes that may directly or indirectly affect community budgets are the following:

The GDP indicator for 2020 is set at UAH 3,985.5 billion, which is $11.6 \%$ less than expected in the Government's previous forecast, Resolution №555 of 15.05.2019. This figure is only $0.3 \%$ higher than the nominal GDP for 2019, which amounts to UAH 3974.6 billion, the fall in real GDP is expected at 4.8\%. According to the International Monetary Fund (IMF), Ukraine's real GDP will shrink by $7.7 \%$ in 2020 , but will grow by $3.6 \%$ in 2021 (World Economic Outlook, April 2020). The World Bank in the new forecast of Ukraine's economic development (Fighting CORVID-19) predicts that in 2020 Ukraine's real GDP will shrink by $3.5 \%$, and the Cabinet of Ministers forecasts a reduction of $4.8 \%$, after which in 2021 is expected to grow by $3 \%$, in 2022 - by $4 \%$. The World Bank forecasts that in 2020 there will grow in the agro-industrial sector by $1 \%$, in the services sector - a decline of 5.4\%, industry will remain at the level of 2019, with zero growth. The consumer price index in Ukraine, according to World Bank forecasts, will be $8.9 \%$ in 2020, while in the updated Government forecast $-6.8 \%$. Note that GDP is one of the main indicators that determines the level of revenues to state and local budgets. Since the beginning of the decentralization reform and the formation of united territorial communities, the share of revenues of the general fund of local budgets (excluding transfers from the state budget) in GDP has gradually increased - from 6.15\% in 2016 to $6.92 \%$ in 2019 table 1.

Table1. The Ratio of Local Budget Revenues and GDP of Ukraine

\begin{tabular}{|l|c|c|c|}
\hline Years & $\begin{array}{c}\text { Revenues of the general fund of local budgets } \\
\text { (excluding transfers from the state budget) } \\
\text { UAH million }\end{array}$ & $\begin{array}{c}\text { GDP, } \\
\text { million UAH }\end{array}$ & $\begin{array}{c}\text { The share of local budget } \\
\text { revenues in GDP }\end{array}$ \\
\hline 2014 & 80230,1 & 1586915 & $5,06 \%$ \\
\hline 2015 & 101574,7 & 1988544 & $5,11 \%$ \\
\hline 2016 & 146648,3 & 2385367 & $6,15 \%$ \\
\hline 2017 & 192671,5 & 2983882 & $6,46 \%$ \\
\hline 2018 & 234105,1 & 3560596 & $6,57 \%$ \\
\hline 2019 & 275169,8 & 3974564 & $6,92 \%$ \\
\hline
\end{tabular}

Source: generated and supplemented by authors

Due to the given current trends, we can predict that in 2020 the share of local budget revenues in GDP will be approximately $7.1-7.3 \%$. For 2020 , the revenues plan of the general fund of local budgets was approved in the amount of UAH 292.8 billion, which is $7.3 \%$ of the GDP approved in the revised forecast of the Government (UAH 3985.5 billion). Thus, the approved indicator of local budget revenues correlates with the existing trends that characterize the ratio of local budget revenues to GDP. It should be noted that the indicator of local budget revenues for 2020 is only $6.4 \%$ higher than the actual revenues for 2019 , lower than the projected inflation rate. At the same time, the adequacy of local budget targets to the current conditions of economic development can be assessed in more details in the following reporting periods, as the effects of restrictive measures on business and adopted laws that will reduce revenues will appear from the second quarter of 2020 year.

In the revised forecast, the fund for remuneration of employees and financial support of servicemen was reduced by $8.6 \%$, which is UAH 116.7 billion. The wage fund directly affects the income of the Pension Fund of Ukraine. Given the revised forecast of the wage bill, local governments should also review the indicators of socioeconomic development, which were the basis for the formation of local budgets for 2020.

The forecast indicator of the average monthly salary in the revised forecast is UAH 10,706 , which is UAH $1,791.0$ or $14.3 \%$ less than the indicator approved by the Government in 2019. The revised forecast of the average monthly salary is only $2.0 \%$ or UAH 209.2 higher than the actual average monthly salary in 2019. That is, a significant reduction in wage growth is expected, which will have a direct impact on budget revenues. In addition, in 2020, real wages (nominal wages including the consumer price index) are expected to decrease by $4.5 \%$ (or 14.6 percentage points) (absolute deviation of the indicators defined as a percentage), while according to the results of 2019 , real wages increased by $9.8 \%$.

We will note that on April 13, 2020 the Verkhovna Rada of Ukraine approved changes to the State budget of Ukraine for 2020 which reduced the expected sum of 
incomes of the state budget by 120 billion UAH or by $11 \%$. The planned indicator of personal income tax revenues, which is credited to the state budget (has been reduced by UAH 18.5 billion or $14.3 \%$ ). Approximately the same amount should be expected to reduce PIT revenues in local budgets. Today, the PIT plan approved by local budgets is UAH 183.7 billion. Thus, the estimated losses of local budgets may amount to UAH 23 billion. In addition, according to the introduced "Law" 40540 from 30.03.2020 "tax holidays" on payment for land and real estate in March 2020, local budgets may lose another about 3.5 billion UAH (while compensating for losses of local budgets from such norms in the State budget are not provided). In addition, local budget revenues will be affected by the general decline in economic activity during the quarantine period, which will be felt as early as April, as well as the deterioration of payment and tax discipline.

The expected unemployment rate increased by $16 \%$ (from $8.1 \%$ to $9.4 \%$, or 1.3 percentage points). At the same time, the IMF forecasts that the unemployment rate in Ukraine will reach $10.1 \%$ by the end of the year (World Economic Outlook, April 2020). The number of unemployed populations is calculated according to the methodology of the International Labor Organization. According to this methodology, a person is considered unemployed if he / she is within four weeks: did not have a job, was looking for a job, was ready to start work. Unemployment is an important indicator of the general state of the economy. Based on the methodology of calculation and the number of able-bodied population, the expected number of unemployed can reach 1.6 million people.

Thus, according to the State Employment Service, as of April 13, 2020, 388 thousand Ukrainians are unemployed, which is $22 \%$ more than in the same period of 2019 . The most critical situation is registered in five regions of Ukraine - in Lviv, Kharkiv, Poltava, Dnipropetrovsk, and Zaporizhia.

Inflation at the end of 2020 is expected to be at $11.6 \%$, which is 6.1 percentage points above the forecast previously approved by the Government. According to IMF calculations, the inflation forecast is more optimistic and is 7.7\%, and in 2021 5.9\% (World Economic Outlook, April 2020).

Due to all given the above information, local governments should analyze the actual indicators of economic development of the territories, compare them with the forecast parameters on the basis of which the formation of local budgets for 2020, and, if necessary, add adjustments. It is also advisable to consider the following issues: to limit (at least temporarily) budget expenditures that are not priority; if possible, postpone scheduled overhauls (except for emergency works); suspend the filling of vacancies and the payment of optional surcharges and bonuses (except for medical staff, of course); analyze the need for funding for certain local programs and activities, and apply other measures aimed at saving budget funds and balancing budgets.

Table 2. Comparative Data of the Main Macroeconomic Indicators of Economic and Social Development of Ukraine, 2020

\begin{tabular}{|c|c|c|c|c|c|}
\hline Gross Domestic Product & $\begin{array}{c}\text { Actual } \\
\text { figure } 2019\end{array}$ & $\begin{array}{c}\text { Approved } \\
\text { (Resolution of } \\
\text { the Cabinet } \\
\text { of Ministers } \\
\text { of Ukraine № } \\
555 \text { of May } \\
\text { 15, 2019) }\end{array}$ & $\begin{array}{c}\text { Clarified } \\
\text { (Resolution of } \\
\text { the Cabinet } \\
\text { of Ministers } \\
\text { of Ukraine № } \\
253 \text { of March } \\
29,2020 \text { ) }\end{array}$ & $\begin{array}{l}\text { Change of the } \\
\text { specified } \\
\text { indicators } \\
\text { with the } \\
\text { approved }\end{array}$ & $\begin{array}{l}\text { Change of the } \\
\text { specified } \\
\text { indicators with } \\
\text { the indicator of } \\
2019\end{array}$ \\
\hline Nominal, billion UAH & 3974,6 & 4510,8 & 3985,5 & $-11,6 \%$ & $+0,3 \%$ \\
\hline Interest to the previous year & 103,2 & 103,7 & 95,2 & $-8,5$ & $-8,0$ \\
\hline \multicolumn{6}{|c|}{ Consumer price index } \\
\hline Average to the previous year, $\%$ & 107,9 & 106,4 & 106,8 & $+0,4$ & $-1,1$ \\
\hline $\begin{array}{l}\text { December to December of the } \\
\text { previous year }\end{array}$ & 104,1 & 105,5 & 111,6 & $+6,1$ & $+7,5$ \\
\hline $\begin{array}{l}\text { Industrial producer price index } \\
\text { (December to December of the } \\
\text { previous year), \% }\end{array}$ & 92,6 & 108,2 & 112 & $+3,8$ & $+19,4$ \\
\hline $\begin{array}{l}\text { Profit of profitable enterprises, billion } \\
\text { UAH }\end{array}$ & $*$ & 937,6 & 749,3 & $-20,1 \%$ & \\
\hline
\end{tabular}


Електронне наукове фахове видання з економічних наук “Modern Economics», №23 (2020), 180-186 https://modecon.mnau.edu.ua | ISSN 2521-6392

\begin{tabular}{|c|c|c|c|c|c|}
\hline & & & & & Продовження: \\
\hline $\begin{array}{l}\text { Fund for remuneration of employees } \\
\text { and financial support of servicemen, } \\
\text { billion UAH }\end{array}$ & $*$ & 1352,2 & 1235,5 & $-8,6 \%$ & \\
\hline \multicolumn{6}{|c|}{ Average monthly wages, gross: } \\
\hline Nominal & 10496,8 & 12497,0 & 10706,0 & $-14,3 \%$ & $2,0 \%$ \\
\hline $\begin{array}{l}\text { nominal, adjusted for the consumer } \\
\text { price index, interest to the previous } \\
\text { year }\end{array}$ & 109,8 & 110,1 & 95,5 & $-14,6$ & $-14,3$ \\
\hline $\begin{array}{l}\text { Number of people engaged in } \\
\text { economic activities aged } 15-70 \text {, million } \\
\text { people }\end{array}$ & 16,43 & 16,51 & 16,33 & $-1,1 \%$ & $-0,6 \%$ \\
\hline $\begin{array}{l}\text { Unemployment rate of the population } \\
\text { aged } 15-70 \text { years according to the } \\
\text { methodology of the International } \\
\text { Labor Organization, interest on the } \\
\text { labor force of the relevant age }\end{array}$ & 8,7 & 8,1 & 9,4 & $+1,3$ & $+0,7$ \\
\hline $\begin{array}{l}\text { Labor productivity, interest to the } \\
\text { previous year }\end{array}$ & $*$ & 103,2 & 96,7 & $-6,5$ & \\
\hline $\begin{array}{l}\text { The balance of trade, determined by } \\
\text { the balance of payments methodology, } \\
\text { is one million US dollars }\end{array}$ & $-3633,1$ & $-14882,0$ & $-8289,0$ & $-44,3 \%$ & $128,2 \%$ \\
\hline \multicolumn{6}{|c|}{ Export of goods and services: } \\
\hline million US dollars & 63675,6 & 68642,0 & 59911,0 & $-12,7 \%$ & $-5,9 \%$ \\
\hline to the previous year, $\%$ & 111,2 & 107,8 & 94,5 & $-13,3$ & $-16,7$ \\
\hline \multicolumn{6}{|c|}{ Import of goods and services: } \\
\hline million US dollars & 67308,7 & 83524,0 & 68200,0 & $-18,3 \%$ & $+1,3 \%$ \\
\hline to the previous year, $\%$ & 106 & 109,6 & 90 & $-19,6$ & $-16,0$ \\
\hline
\end{tabular}

* no reporting data for 2019

** pp-percentage points (absolute deviation of the indicators defined in percent)

Source: [8]

An important indicator that characterizes the socioeconomic development of the country is income per capita. Last year (2019) in Vinnytsia region, the per capita income was $64,729 \mathrm{UAH}$, while the average salary of a fulltime employee was lower than the national average and amounted to 9,299 UAH.

Thus, in Ukraine in 2019, the disposable income per capita was $67,528 \mathrm{UAH}$, and the average salary of full-time employees reached 10,497 $\mathrm{UAH}$.

The first place in the ranking of regions by income per capita in 2019 is occupied by Kyiv and is 165,054 UAH, the

last - Luhansk region, excluding data from the occupied territories - 24,477 UAH. In the capital, a full-time employee receives an average of 15,776 hryvnias, which is the highest salary in Ukraine. Social and economic indicators of Ukraine's development Vinnytsia is in the tenth place in the ranking with a disposable income of $64,729 \mathrm{UAH}$. The average salary in our city is 9,299 UAH, which is lower than the national average. In terms of population, Vinnytsia region occupies a position between Poltava and Zaporizhia, although smaller in area. 


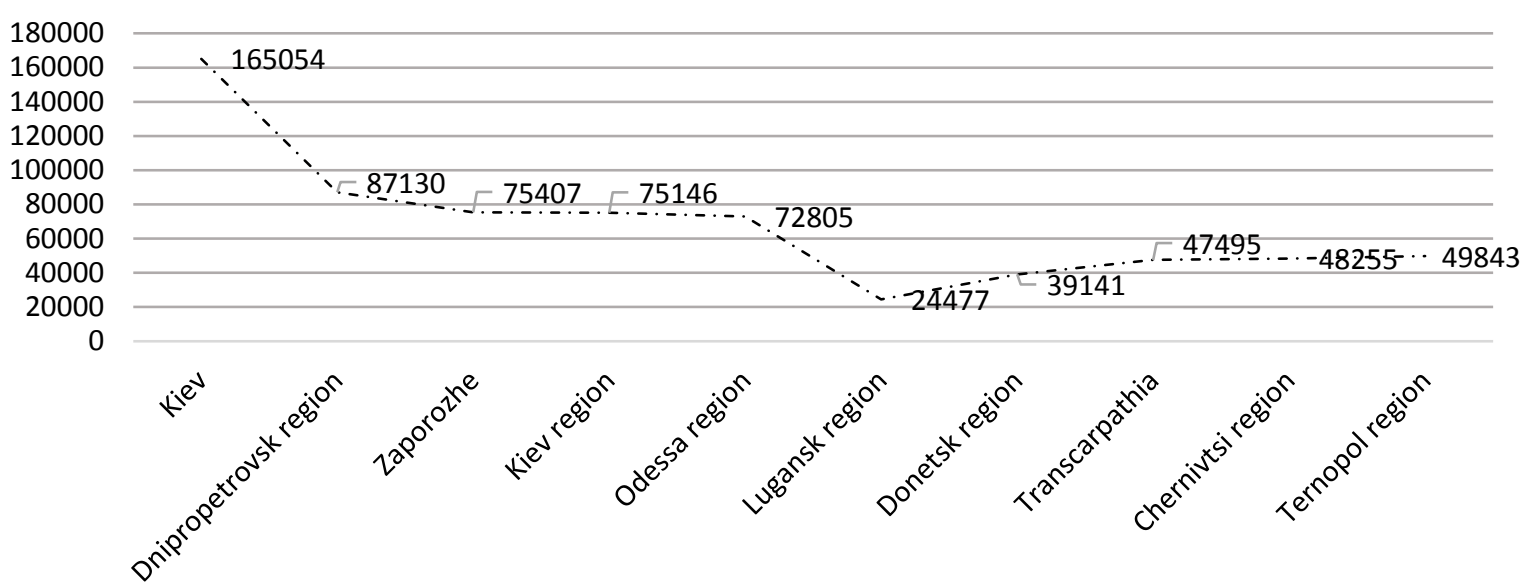

Figure 1 - Ranking of cities by income per capita in 2019, UAH

Source: self-formed

The disposable income in the city of Kyiv per person is 165,054 hryvnias, with the highest average salary being 15,776 hryvnias. The city as a capital, has a special status, is a separate territorial unit, so the statistics indicate the level with the regions. Although Kyiv is the smallest in terms of territory, compared to the regions and even the city of Sevastopol, which also has a special status.

According to the population, Kyiv is the third, after Donetsk and Dnipropetrovsk regions, according to the State Statistics of Ukraine on the average number for 2019. The disposable income in the Dnipropetrovsk region per capita is 87,130 hryvnias. The average salary in the Dnipropetrovsk region is among the top five in Ukraine, amounting to 10,751 hryvnias as of 2019 . The region is the second largest in terms of area, after Odesa, and the second largest in terms of average population in 2019.
In the Zaporizhia region, the income per capita is 75,407 hryvnias. Zaporizhzhia region ranks fifth in the amount of UAH 10,480 in terms of the average salary of full-time employees. The region ranks 9 th in terms of area and population.

Kyiv region has an income per person: 75,146 hryvnias. The average monthly salary in the region is among the top three - 11,003 hryvnias. In terms of area and population, Kyiv region is one step higher than Zaporizhia region.

The largest area of the country is $33,310 \mathrm{~km} 2$, Odessa region, and the population is ranked sixth in Ukraine. The income per person is UAH 72,805, the average monthly salary of full-time employees of Odesa region in 2019 is 9,246 UAH, which is less than in Lviv, Poltava and Mykolayiv. However, it is close to the average salary of Zakarpattia region in the amount of UAH 9,202.

average salary in Ukraine 10497 UAN

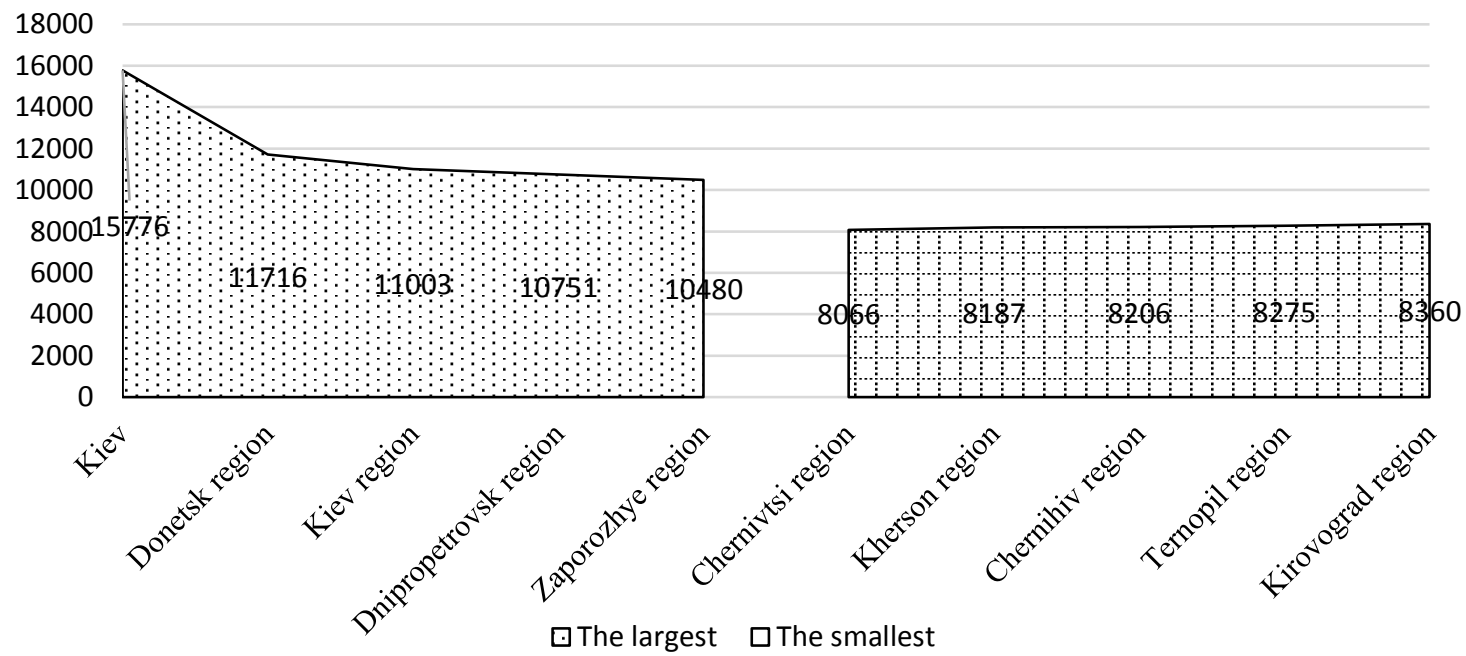

Figure 2 - Average salary for full-time employees in 2019, UAH

Source: self-formed

Poltava. Disposable income per person: 71,627 UAH, and the average monthly salary for 2019 is 9,846 UAH.
Lviv region. Disposable income per person: 65,691 $\mathrm{UAH}$. The region is in the top five $(2,498,683$ people), 
although it ranks 17 th in terms of area. The average salary in 2019 is 9,271 UAH.

Kharkiv region. The disposable income per capita is $65,534 \mathrm{UAH}$, the region is among the leaders in terms of population in 2019, one step higher than Lviv, and slightly less than the city of Kyiv: 2,651,394 people, and by area it is the fourth region in the country. As for the average salary, it is below the average in Ukraine and is 9,081 UAH.

In Sumy region, the income per capita is 65,310 $\mathrm{UAH}$, and the average salary is $8,579 \mathrm{UAH}$, which is close to the lowest figures in the country.

The income of citizens of Vinnytsia region per person is $64,729 \mathrm{UAH}$, compared to the average salary, it is 9,299 $\mathrm{UAH}$, which is lower than the national average. In terms of population, Vinnytsia region occupies a position between Poltava and Zaporizhia regions, although it is smaller in area than these regions [8].

The income per person in the amount of 63,685 hryvnias reaches in the Mykolayiv area. The average salary is 9,976 UAH, lower than the national average, but slightly higher than in the Odessa region.

Zhytomyr region has an income per person of 61,961 $\mathrm{UAH}$, but the average salary in the region is close to the lowest and is 8,528 $\mathrm{UAH}$. Zhytomyr region is the fifth largest in Ukraine, and the average population (1,214,971 people) is lower than in the Transcarpathian region $(1,252,463$ people), which is among the smallest in the territory.

The third largest region in Ukraine, after Odessa and Dnipropetrovsk, but in terms of population is in the top three with the lowest rate $-989,978$ people (average for 2019) - Chernihiv region. The disposable income per person is 58,904 $\mathrm{UAH}$. In terms of the average salary, it also ranks low at UAH 8,206, lower only in Chernivtsi and Kherson.

The average salary of $8,838 \mathrm{UAH}$ is in Cherkasy region, the figure is almost the same as in Luhansk and Rivne regions, but the income per citizen is 58,808 UAH.

Kirovohrad Region ranks 15th among regions, the Autonomous Republic of Crimea and cities with a special status. In addition, in terms of population, the region is among the three regions with the lowest rate of 932,914 people. And ranks fifth from the end in terms of average salary in the amount of 8,360 UAH. However, the income per capita reaches 58,290 UAH in 2019.

Khmelnytsky region has an average salary of 8,672 $\mathrm{UAH}$, which is almost the level of Volyn region, but lower than the average in Ukraine. The disposable income per person is $58,008 \mathrm{UAH}$.

In the Kherson region, the disposable income per capita reaches $57,110 \mathrm{UAH}$, the region took second place in terms of the lowest average salary in 2019 in the amount of $8,187 \mathrm{UAH}$.

Income per capita in the amount of 55,537 UAH was recorded in Ivano-Frankivsk region, which is one of the five smallest regions in terms of area, but outnumbers Zhytomyr, Mykolayiv, and Kherson regions in terms of population. The average salary is 8,817 UAH in 2019.
The average salary is $8,967 \mathrm{UAH}$, but the income per capita reaches 54,183 UAH. And although the Rivne region is larger than Ivano-Frankivsk, the number of residents is smaller - 1,154,071 people in 2019.

Income in the Volyn region per capita is 52,879 UAH. Volyn region is located on the 20th place in terms of size, but the average salary reaches 8,663 hryvnias, the population is close to Kherson region in terms of population.

Ternopil region has an income per capita of 49,843 $\mathrm{UAH}$. It is a small region, larger only than Zakarpattia and Chernivtsi, and has the lowest average salary of UAH 8,275 , which puts it in fourth place after Chernivtsi, Kherson and Chernihiv [8].

The smallest and largest Chernivtsi region, the income per citizen is $48,255 \mathrm{UAH}$. The average monthly salary of full-time employees is also the lowest among all regions in the amount of UAH 8,066.

Transcarpathian region. Disposable income per person: 47,495 UAH. Small in area, smaller only Chernivtsi, but in number $(1,252,463$ people in 2019) is dominated by many regions, such as: Zhytomyr, Volyn, Mykolayiv, Rivne, Sumy, Kherson, Cherkasy. The average salary is $9202 \mathrm{UAH}$ in 2019.

Donetsk region with the largest average number in $2019-4,135,969$ people and an income per person of 39,141 UAH. These data are formed on the basis of available administrative data on the state registration of birth and death and changes in the registration of residence, according to the state statics service.

Data on the revenues of regions are received by the State Statistics Service only from the territories controlled by Ukraine, which explains the low indicators of two regions: Donetsk and Luhansk, some of which are temporarily occupied. The average salary in Donetsk region is one of the highest in Ukraine in the amount of 11,716 on the second step after the city of Kyiv.

The average salary is $\mathrm{UAH} 8,731$ in Luhansk region, which is less than in Cherkasy, Rivne, Ivano-Frankivsk, and Lviv regions. Luhansk region is larger than Donetsk region, and they are located on the 10th-11th place in the list of regions by territory size. Disposable income per person is 24,477 hryvnias.

As of November 1, 2018, according to the state statistics of Ukraine, about 42 million people live on its territory, 2 million 906 thousand people live in the city of Kyiv, which is $14.4 \%$ of the total number. The population of Dnipropetrovsk region is 3 million 208 thousand people, which is $13.1 \%$ of the population.

Conclusions. Create a favorable environment for the development and conduct of business in Ukraine, making the market as fair and transparent as possible, and reduce regulation to the minimum necessary.

- Create favorable conditions for the development of a strong and competitive SME sector, providing access to finance, markets and creating infrastructure for small and medium business development. 
- Ensure deep reform of the energy sector, creating the conditions for Ukraine to achieve energy independence.

- Get rid of burdensome ballast for the country's budget - unprofitable state-owned enterprises, ensure effective management of strategically important assets.

- Ensure transparent and effective management of land resources, the formation of capable territorial communities by transferring to their disposal agricultural lands of state ownership as the main means of production and economic development of territories.
- Make transport services in Ukraine high-quality and accessible, and infrastructure modern and integrated into international transport networks.

- Completion of these tasks and each of them separately will strengthen the state budget, provide conditions for modernization of production, Ukraine's inclusion in regional and global value chains, accelerate investment in the Ukrainian economy and create new jobs. All this will open new opportunities for the citizens of Ukraine and as a result will positively affect the quality of life of every inhabitant of the country.

\section{References:}

1. Popovych, O., Didenko, N. (2016). Interpretation of the economic essence of the category "income". Economy and society, 7 , 975-978.

2. Pronko L., Kolesnik, T. Samborska, O. Activities of united territorial communities as a body of local government in the conditions of power decentralization in Ukraine. Baltic Journal of Economic Studies, 4(2), 184-190.

3. Samborska, O., Kolesnik, T. (2019). Assessment of the current state and directions of development of united territorial communities in the conditions of decentralization. Economics of agro-industrial complex, 11.

4. Samborska, O. (2020). Economic analysis for forecasting and prospective planning of economic processes of local selfgovernment. The scientific heritage, 7 (46), 21-28.

5. Samborska, O. (2019). Human capital as a factor of economic growth of Ukraine. Economics of agro-industrial complex. International research and production journal, 6, 64-72.

6. Samborska, O. (2018). Strategy of Government of Managament State Land: Foreign Experience. Multidisciplinary Scientific Journal, 3, 15-19.

7. Yatsun, O. M. (2014). Liudskyi kapital yak chynnyk ekonomichnoho zrostannia [Human capital as a factor of economic growth]. Visnyk Akademii pratsi i sotsialnykh vidnosyn Federatsii profspilok Ukrainy, 2, 95-100 [in Ukrainian].

8. URL: https://decentralization.gov.ua/news/12362. 